\title{
APROPRIAÇÃO DA CULTURA DIGITAL SOB A UTILIZAÇÃO DE MEMES: PRODUZIR E OCUPAR ESPAÇOS NAS REDES SOCIAIS EM PROL DO ENSINO DE LÍNGUAS
}

\author{
Digital culture appropriation under the use of memes: producing and \\ occupying space on social media on behalf of language learning
}

\author{
Carolina Favaretto SANTOS \\ Universidade Estadual de Londrina \\ carolinafavaretto7@gmail.com \\ https://orcid.org/0000-0002-5137-0066 \\ Cláudia Cristina FERREIRA \\ Universidade Estadual de Londrina \\ claucrisfer@sercomtel.com.br \\ https://orcid.org/0000-0003-4605-3733
}

\begin{abstract}
RESUMO: Em tempos de pandemia, sobretudo, as tecnologias digitais têm contribuído para ministrarmos aulas remotas tanto na modalidade síncrona, como assíncrona, buscando promover benefícios ao contexto educacional e aos envolvidos no processo de ensino e aprendizagem, além de diversificar e inovar as aulas. A proposta deste artigo é dialogar sobre a cultura digital, as contribuições e os desdobramentos desses recursos auxiliares no processo de ensino e aprendizagem de línguas estrangeiras/adicionais a partir de memes e sob o viés da associação de língua e cultura. Além de reflexões teóricas, sugerimos exemplos de propostas didáticas para professores adaptarem ao seu contexto profissional, de acordo com o perfil e as necessidades dos aprendizes. Para tanto, a respeito da indissociabilidade de língua e cultura, valemo-nos dos preceitos de Araújo e Figueiredo (2015), Durão (1999, 2002), Ferreira (2018, 2020), Ferreira e Durão (2020). Por sua vez, a respeito de memes, baseamo-nos em Anecleto e Filha (2017), Calixto (2019), Cani (2019), Recuero (2006), Shifman (2014) e Wiggins (2019). Podemos concluir que as tecnologias digitais requerem capacitação por parte de professores e alunos, objetivos bem delineados e adaptados ao contexto de ensino, além de criatividade e abertura para navegar nesse universo lúdico, inovador e repleto de possibilidades. PALAVRAS-CHAVE: Recursos digitais; memes; línguas estrangeiras/ adicionais.
\end{abstract}

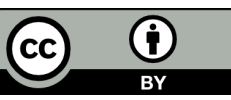




\begin{abstract}
In pandemic times, above all, digital technologies have contributed to giving remote classes in both synchronous and asynchronous modes, trying to bring possible benefits to the educational context and those involved in the teaching and learning process, in addition to diversifying and innovating classes. The purpose of this article is to dialogue about digital culture, the contributions and developments of these auxiliary resources in the process of teaching and learning foreign/additional languages from memes and in the association of language and culture. In addition to theoretical reflections, we suggest examples of didactic proposals for teachers to adapt to their professional context, according to the profile and needs of the learners. Therefore, regarding the inseparability of language and culture, we use the precepts of Araújo and Figueiredo (2015), Durão (1999, 2002), Ferreira (2018, 2020), Ferreira and Durão (2020). Regarding memes, we draw on Anecleto e Filha (2017), Calixto (2019), Cani (2019), Recuero (2006), Shifman (2014) and Wiggins (2019). We can conclude that digital technologies require more attention on the part of teachers and students, well-defined objectives, as well as adaptation to the teaching context, creativity and openness to navigate this playful, innovative and full of possibilities universe. KEYWORDS: Digital resources; memes; foreign/additional languages.
\end{abstract}

\title{
CONSIDERAÇÕES PRELIMINARES
}

As tecnologias digitais de informação e comunicação (TDIC) têm cada vez mais exercido papel ativo na vida dos indivíduos, corroborando para o aumento da inserção desses recursos em sala de aula, com o propósito de aproximar práticas cotidianas de práticas pedagógicas, a fim de tornar o processo de ensino e aprendizagem mais significativo para o aluno. Portanto, com o advento da internet, juntamente com o avanço tecnológico e digital, além do surgimento de novos gêneros, há também o começo de novos tipos de interações e relações do sujeito com o mundo.

Como resposta à mudança e evolução dos meios de comunicação, e à manifestação de novas formas de expressão e representação, professores de línguas estrangeiras/adicionais podem se beneficiar com o uso destes novos gêneros em suas aulas. Nesse viés, identificamos os memes como parte integrante dos novos recursos virtuais em questão, possibilitando explorar não só capacidades linguísticas do aprendiz da língua estrangeira/adicional, como também a competência comunicativa e intercultural, "a qual prioriza o aspecto cultural do ensino da língua e inclui a capacidade de estabilizar a própria identidade no processo de mediação entre 
culturas e a de ajudar outras pessoas a estabilizar a sua." (FERREIRA, 2013, p. 5). Esta prática colabora para a reflexão e criticidade diante de temas atuais.

Como formadores de presentes e futuros leitores, professores deveriam considerar o uso de instrumentos de ensino que fomentem o pensamento crítico. Por serem demasiadamente compartilhados nas redes sociais, memes requerem maior cuidado, responsabilidade e preparo por parte dos leitores quanto ao que é escrito, compartilhado e postado nessas plataformas digitais.

A propagação dos textos de mídia nos ajuda a expressar quem somos, a reforçar nossos relacionamentos pessoais e profissionais, a fortalecer nossas relações uns com os outros, a construir uma comunidade e a conscientizar mais pessoas dos assuntos com os quais nos preocupamos. O compartilhamento da mídia além das fronteiras culturais aumenta a oportunidade de ouvir outras perspectivas e de desenvolver empatia por perspectivas diferentes da nossa. (JENKINS; FORD; GREEN, 2014, p. 366)

Diante do exposto, entende-se que língua e cultura são indissociáveis, pois: "uma das principais formas de expressão de um povo é sua língua, mas a língua anda de mãos dadas com a cultura" (DURÃO, 2002, p. 6). Portanto, cada língua possui seus próprios valores culturais, sendo necessário seu entendimento para obter melhor resultado na comunicação. Ao enxergar a língua como um elemento social, inerente à cultura do falante, percebe-se que o ensino de uma língua estrangeira/adicional não deve limitar-se ao âmbito gramatical, estrutural e fonético, por exemplo. É preciso abranger aspectos culturais durante as aulas, tanto da língua alvo, quanto da língua materna, colaborando para a ampliação de visão de mundo e criticidade do aluno e promover o aumento das oportunidades do contato com a alteridade.

O trabalho com matizes culturais no ensino de línguas propicia o desenvolvimento da interculturalidade, onde há oportunidade de reflexão por meio da "exploração de um espaço intermediário, pelo contraste entre a língua/cultura própria e a língua/cultura alvo" (GIMENEZ, 2001). Por sua vez, Ferreira (2020, p. 5) chama atenção para a contribuição de matizes culturais atreladas ao processo de ensino e aprendizagem para "minimizar ou erradicar visões fragmentadas, generalizações, estereótipos e preconceitos no que tange à diversidade em geral". Nesse sentido, objetivamos com este artigo, dialogar sobre tecnologias digitais e memes no ensino, além de apresentar propostas pedagógicas para o uso de memes no ensino de línguas estrangeiras/adicionais, sob um viés intercultural e propor reflexões acerca do uso consciente das novas tecnologias. 


\section{REFERENCIAL TEÓRICO}

\section{Desvendando caminhos: em busca de mediações para compreender a alteridade}

Ao se pensar no processo de ensino e aprendizagem de língua estrangeira/ adicional, é de suma importância considerarmos a inseparabilidade de língua e cultura, uma vez que "a cultura faz parte da construção social do indivíduo em sua comunidade, que, por sua vez, se dá através da linguagem" (ARAÚJO; FIGUEIREDO, 2015, p. 63). Para fins esclarecedores, a definição de cultura que subjaz este artigo é a preconizada por Araújo e Figueiredo (2015, p. 63), onde os autores a caracterizam como sendo um "conjunto de padrões, de valores, experiências, crenças de uma sociedade, organização, grupo, $[\ldots]$ parte essencial dos indivíduos passada de geração a geração". Desse modo, é papel do professor refletir a respeito de práticas pedagógicas que desenvolvam o ensino não somente de regras e estruturas, mas, também, de questões culturais da língua alvo.

Nesse sentido, o componente cultural desempenha um papel importantíssimo no processo de ensino e aprendizagem das línguas estrangeiras. Nas palavras de De Greve e Van Passel (1971) "ensinar uma língua significa ipso facto ensinar a cultura, já que em sua condição de fenômeno, a língua representa em essência um dos principais aspectos da cultura de uma comunidade." Portanto, aprender uma língua nova significa dominar "não só o conhecimento das propriedades formais da língua como sistema, mas também um conhecimento do uso social da língua e de seu funcionamento nas situações comunicativas diárias" (GIMENO MENÉNDEZ, 1993 apud DURÃO, 2002, p. 6-7)

Por expressar contextos sociais e culturais diversos, o uso de memes nas aulas de língua estrangeira/adicional fomenta o trabalho cultural além do linguístico estrutural e funcional do idioma. No processo de ensino e aprendizagem, é de extremo interesse que tenhamos consciência de que "a nossa capacidade de entender o mundo desenvolve-se dentro de um contexto cultural, de modo que as palavras que usamos refletem a sociedade na qual essas palavras se forjaram" (DURÃO, 2002, p. 2). Ou seja, as línguas são artefatos socioculturais, constituídos de diferentes origens, costumes, tradições, perspectivas e visões de mundo, funcionando como mediadores para a compreensão da cultura do próximo.

$\mathrm{O}$ contato com uma língua estrangeira/adicional propicia o recebimento de exemplos e usos da língua-alvo. Esses exemplos podem funcionar como insumo para modelos e consequentes inferências linguísticas. No entanto, tais inferências podem adentrar o âmbito cultural, fazendo com que esse contato com a outra língua estabeleça 
uma conexão com diferentes identidades, opiniões e signos particulares de cada sociedade. Nesse ínterim, o trabalho com matizes (inter)culturais em sala de aula se faz pertinente, visto que ao aprenderem um novo idioma, os alunos descobrirão novos modos de interpretação e comunicação. Vale salientar que adotamos o termo (inter) cultural porque pode ser a respeito de fatores culturais no âmbito nacional, em nosso caso, somente as culturas brasileiras com suas especificidades de acordo com cada região desse imenso e belo país (cultural) e/ou matizes que envolvem diferentes culturas e línguas em nível internacional, ou seja, culturas brasileiras em contraste com outras culturas de países estrangeiros.

Com base no que abordamos até o momento, convidamos para uma reflexão acerca do ensino de línguas estrangeiras/adicionais pelo viés da abordagem intercultural. Concordamos com conceitos apresentados por Araújo e Figueiredo (2015, p. 8): "Assim, podemos dizer que possuir competência comunicativa intercultural significa não ter somente domínio da estrutura da língua alvo, mas, também, reconhecer as coisas que fazem realmente sentido para a comunidade da qual está aprendendo a língua e interagindo por meio dela". Isso significa que há observação e ponderação sobre a cultura materna (ou nativa) e a cultura alvo, junto com seus aspectos linguísticos. Esse diálogo entre diferentes costumes e contextos pode levar professores e alunos a um processo de mudança, conscientizando criticamente os falantes da língua estrangeira/adicional no que diz respeito à língua e ao contexto em que é utilizada. Desse modo, oportuniza-se uma possível interação entre encontros linguístico-culturais, viabilizando um olhar mais compreensível no que se refere à própria cultura, quanto à cultura do outro.

A escolha por trabalhar a interculturalidade por meio do gênero meme se dá pelo fato de que este recurso promove práticas comunicativas extralinguísticas, as quais revelam características identitárias de falantes de uma língua em específico. Tais características se apresentam de maneira multimodal, abordando escolhas lexicais inerentes à cultura em questão, como fraseologismos ou unidades fraseológicas, que são: "sequências linguísticas que constituem o objeto de estudo da Fraseologia, como sentenças proverbiais, expressões idiomáticas (EI), pragmatemas e fórmulas situacionais, colocações, locuções fixas, frases feitas, clichês e chavões" (MONTEIRO-PLANTIN, 2012, p. 15). Assim como parêmias (provérbios), que são "unidades linguístico-culturais sintéticas, moralizantes e ritmadas, repassadas de geração em geração, com sentido metafórico, com diferentes funções, de acordo com o almejado pelo interlocutor" (FERREIRA; DURÃO, no prelo) gestualidades, paralinguagem, comportamentos, atitudes e costumes.

Desse modo, "justifica-se, ainda mais, a implementação de aspectos culturais no contexto de ensino e aprendizagem, posto que ao conhecer o outro, sensibilizamo-nos Revista X, v. 16, n. 2, p. 608-632, 2021. 
a entender sua realidade, sem julgamentos indevidos" (FERREIRA, 2020, no prelo). Este pensamento apoia-se nas discussões propostas por Walsh (2019), envolvendo interculturalidade e sua associação a políticas identitárias, em busca da "construção de um mundo diferente" (WALSH, 2019, p. 6).

Nas palavras de Ferreira (2018, p. 492), “da união entre língua e cultura, surgiram os culturemas". Com base em Luque Durán (2009) e Luque Nadal (2009), Ferreira (2018) conceitua culturemas como sendo

[...] unidades semiótico-culturais infinitas, verbais ou paraverbais, linguísticas ou extralinguísticas, compartilhadas por determinada comunidade $\mathrm{X}$, que servem de referência e modelo para que se comparada a outra, possam identificá-las como parte da identidade da comunidade X e não da comunidade Y (FERREIRA, 2018, p. 508).

Por conseguinte, compreender a natureza de culturemas faz-se relevante para este estudo, posto que essas unidades podem levar o aluno a uma ressignificação de dados linguístico-culturais da língua alvo. Além disso, memes são textos repletos de símbolos não-verbais manifestados por meio de culturemas, abrindo espaço para discussões e indagações críticas em sala de aula. Para exemplificar, no quadro 1, mencionamos alguns elementos não-verbais presentes em memes:

Quadro 1: Elementos não-verbais.

\begin{tabular}{|c|c|}
\hline $\begin{array}{l}\text { Elementos contemplados pela } \\
\text { comunicação não-verbal }\end{array}$ & $\begin{array}{c}\text { Memes que apresentam elementos não- } \\
\text { verbais }\end{array}$ \\
\hline $\begin{array}{l}\text { Cronêmica: está atrelada à percepção } \\
\text { e à organização de tempo, que acarreta } \\
\text { atitudes comportamentais próprias em } \\
\text { cada comunidade linguístico-cultural. }\end{array}$ & $\begin{array}{l}\text { Quando seu amigo estrangeiro/gringo } \\
\text { aparece as } 6 \text { horas numa festa que vai } \\
\text { começar as } 6 \text { horas. } \\
\text { Fonte: https://images } 3 . \text { memedroid.com/images/ } \\
\text { UPLOADED475/5d529ff001bb4.jpeg. Acesso } \\
\text { em: } 14 \text { jan. } 2021 \text {. } \\
\text { \#PraCegoVer: Fotografia, acima a frase: Quando seu amigo } \\
\text { estrangeiro/gringo aparece } 6 \mathrm{~h} \text { numa festa que vai começar } \\
\text { às } 6 \mathrm{~h} \text {. Uma pessoa olhando para todos os lados no centro de } \\
\text { uma sala organizada para festa. }\end{array}$ \\
\hline
\end{tabular}


Cinésica: refere-se à linguagem corporal, contemplando, por essa razão, cinco áreas: contato visual, gestos, expressões faciais, postura, movimentos da cabeça.

Proxêmica: refere-se ao uso do espaço requerido dos interlocutores nos processos comunicativos. Existem três diferentes níveis de organização de espaço: a distância rígida, a distância semirrígida e a distância informal. Esta última se subdivide em: distância íntima $(15$ a $50 \mathrm{~cm})$, pessoal $(40 \mathrm{~cm}$ a $1,2 \mathrm{~m})$, social $(70 \mathrm{~cm}$ a $4 \mathrm{~m})$ e pública (4 a 9m).

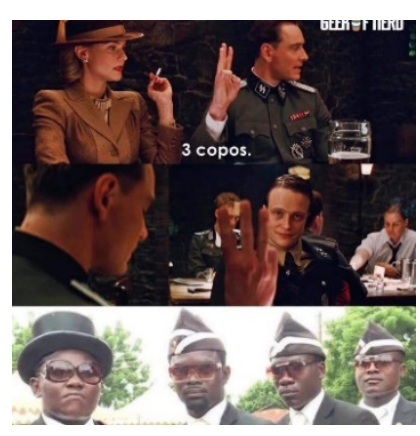

Fonte: https://i.pinimg.com/originals/75 /9c/2b/759c2bee5a0b6f52e2b4d57e74151ecc. jpg. Acesso em: 14 jan. 2021.

\#PraCegoVer: Fotografia dividida em 3 partes. $1^{\text {a. }}$ : num restaurante, meio corpo, um casal, ela usa chapéu e blazer marrom e tem um cigarro em uma das mãos, ele usa uniforme, a mão levantada indicando o numeral três, sobre a imagem a escrita três copos. $2^{\mathrm{a}}$ : do ponto de vista atrás do homem, ele indica o três para outro homem que usa uniforme. $3^{\text {a }}$ : o rosto de quatro rapazes negros, um usa óculos e chapéu de abas arredondadas, os outros três usam óculos e um chapéu sem abas, com detalhes brancos e apontados para cima, são os carregadores de caixão.

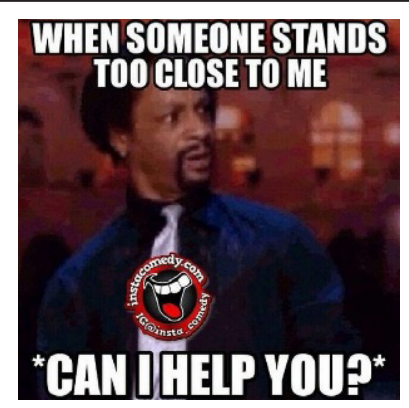

Fonte: https://i.pinimg.com/originals/e6/31/ d6/e631d628d6448310296fff780791c696.jpg.

Acesso em: 14 jan. 2021.

\#PraCegoVer: Fotografia, meio corpo, ator negro, ele usa chapéu e roupa social com gravata, está espantado e olha para o lado, acima a frase "when someone stands too closed to me... can i help you". 


\begin{tabular}{|c|c|}
\hline $\begin{array}{l}\text { Paralinguagem: refere-se às modalidades } \\
\text { da voz, ou seja, às modificações de } \\
\text { altura, intensidade e ritmo que revelam } \\
\text { informações sobre o estado afetivo do } \\
\text { locutor e, também, emissões vocais como } \\
\text { bocejo, riso, grito, tosse. }\end{array}$ & $\begin{array}{l}\text { Mitad de mis problemas son } \\
\text { por culpa del tono de mi voz } \\
\text { Fonte: https://pics.me.me/mitad-de-mis- } \\
\text { problemas-son-por-culpa-del-tono-de-14103803. } \\
\text { png. Acesso em: } 14 \text { jan. } 2021 \text {. } \\
\text { discutiendo cuando en } \\
\text { realidad solo estoy hablando }\end{array}$ \\
\hline
\end{tabular}

Fonte: As autoras, com base em Ferreira e Durão (no prelo).

Antes de exemplificarmos algumas propostas pedagógicas para o uso de memes no ensino de línguas estrangeiras/adicionais à luz de práticas interculturais, destacamos os três tipos de concepções de cultura que constituem um tripé essencial para que se alcance uma aprendizagem mais significativa e eficaz apresentados por Ferreira

Cultura com $\mathbf{C}$ maiúscula: refere-se à visão tradicional de cultura, isto é, remete ao saber literário, histórico, religioso, artístico, musical, que é o conhecimento adquirido a partir da formação acadêmica. É o que se designa "cultura culta" ou "cultura legitimada"; Cultura com c minúscula: refere-se à "cultura popular", quer dizer, ao cotidiano. São traços, especificidades que permitem que determinado grupo seja identificado por suas características culturais. Essas marcas ou características peculiares são típicas de determinada comunidade linguístico-cultural e não outra. É o que os define e agrupa como sendo pertencente a determinada nação, região, cultura; Cultura com k: conhecida como "cultura epidérmica" ou "cultura dos marginalizados", é definida como a capacidade que tem o falante de recorrer os diferentes registros culturais (FERREIRA, p. 13, no prelo, grifo nosso).

Diante das concepções expostas, salienta-se a necessidade de aderir ao uso de instrumentos que utilizem elementos da cultura com c minúsculo. Tais elementos, por se aproximarem mais do cotidiano social e linguístico de uma comunidade, portanto da língua-alvo, têm maiores chances de fomento à solidariedade e respeito a outras culturas. Além disso, podem ocasionar momentos de maior mediação entre diferentes povos, 
colaborando para práticas pedagógicas, sociais, pessoais e culturais. Isso pode ocorrer com o auxílio de recursos visuais e digitais, por exemplo, já que o gênero explorado neste artigo oferece meios multimodais de acesso à linguagem. Como apontado por Araújo e Figueiredo (2015, p. 09), essa práxis busca despertar "habilidades de observação, compreensão, interpretação e tomada de consciência crítica cultural em relação à cultural alvo", além de poder ser trabalhada em vários níveis linguísticos e desenvolver uma consciência intercultural crítica também em relação à própria cultura dos(as) aprendizes.

\section{“Os genes da cultura": memes como instrumentos mediadores do ensino de línguas estrangeiras/adicionais}

Ao considerarmos memes como um fenômeno virtual linguístico-comunicativo (ANECLETO; FILHA, 2017), sua inserção no processo de ensino e aprendizagem de uma nova língua se faz relevante e necessária. Por possuírem rápida circulação nas mídias digitais, como Facebook, Instagram e Twitter, os memes representam diferentes olhares culturais, convívios sociais e conhecimentos de mundo, fazendo com que o aluno possa interagir no mundo de maneira ativa, crítica, consciente e cidadã. Tal fenômeno tem ganhado popularidade nas redes sociais diante de websites criadores e hospedeiros de memes, como: Know your Meme ${ }^{1}$, Meme Base e Museu de Memes ${ }^{3}$.

O conceito de meme foi inicialmente cunhado por Dawkins (2001), no livro " $O$ Gene Egoísta". De acordo com Recuero (2006, p. 3), "Dawkins compara a evolução cultural com a evolução genética, onde o meme é o 'gene' da cultura, que se perpetua através de seus replicadores, as pessoas". Nesse viés, assim como os genes transmitem informações sobre aspectos genéticos, os memes reproduzem e transmitem informações linguísticas e culturais. Do mesmo modo, Calixto (2019, p. 136) define memes como "unidades e imitações que se reproduzem nas redes sociais em forma de contágio viral".

Diferentemente da analogia genética feita por Dawkins, os memes não se perpetuam ou replicam de maneira involuntária pelas pessoas, como os genes fazem. Laineste e Voolaid (2017) assinalam que a circulação dos memes é guiada pelas decisões de seus leitores/usuários. Por conseguinte, estes estão diretamente associados à difusão da comunicação. Com base nos estudos de Dawkins (2001), Recuero (2006) propõe uma classificação dos memes quanto à fidelidade da cópia, longevidade, fecundidade, e ainda acrescenta o critério quanto ao alcance (quadro 2):

\footnotetext{
${ }^{1}$ Disponível em: https://knowyourmeme.com/

${ }^{2}$ Disponível em: https://memebase.cheezburger.com/

${ }^{3}$ Disponível em: https://www.museudememes.com.br/

Revista X, v. 16, n. 2, p. 608-632, 2021.
} 
Quadro 2: Classificação dos memes.

\begin{tabular}{|c|c|}
\hline \multirow{2}{*}{$\begin{array}{l}\text { FIDELIDADE } \\
\text { DA CÓPIA }\end{array}$} & $\begin{array}{l}\text { Replicadores: possuem uma variação reduzida, com alta fidelidade à } \\
\text { cópia original. Função primordial de informar um determinado fato. }\end{array}$ \\
\hline & $\begin{array}{l}\text { Miméticos: são facilmente referenciáveis como imitações, adaptando-se } \\
\text { somente ao meio em que são compartilhados. }\end{array}$ \\
\hline \multirow[t]{2}{*}{ LONGEVIDADE } & $\begin{array}{c}\text { Persistentes: são memes que permanecem sendo replicados por } \\
\text { muito tempo. Podem também desaparecer por um tempo, mas } \\
\text { voltarem a se replicar. }\end{array}$ \\
\hline & Voláteis: têm um curto período de vida e são rapidamente esquecidos. \\
\hline \multirow[t]{2}{*}{ FECUNDIDADE } & $\begin{array}{l}\text { Epidêmicos: se espalham amplamente, como uma epidemia. São } \\
\text { originários de modismos e modos de comportamento. }\end{array}$ \\
\hline & Fecundos: se espalham por grupos menores na rede. \\
\hline \multirow[t]{2}{*}{ ALCANCE } & $\begin{array}{l}\text { Globais: são memes que alcançam os que estão distantes entre si dentro } \\
\text { de uma determinada rede social, não sendo, necessariamente, fecundos. } \\
\text { Aparecem em pontos não próximos. }\end{array}$ \\
\hline & $\begin{array}{l}\text { Locais: são memes propagados por pessoas que estão mais próximas e } \\
\text { que interagem com mais frequência. }\end{array}$ \\
\hline
\end{tabular}

Fonte: As autoras, com base em Recuero (2006, p. 03-05). Disponível em: https://www.seer. ufrgs.br/intexto/article/view/4265. Acesso em: 29 maio 2020.

Se levarmos em conta as classificações que os memes podem apresentar, e seu caráter de "gene cultural" (DAWKINS, 2001 apud RECUERO, 2006, p. 3), evidenciamos a presença quase inata da interculturalidade nesse gênero. Os memes podem operar como disseminadores de ideias e pressupostos culturais, que, se não analisados, interpretados e correlacionados adequadamente de acordo com conjunturas sociais, podem levar à criação e à propagação de preconceitos e estereótipos nas redes sociais. Shifman (2014, p . 18) concorda ao dizer que memes podem ser entendidos como "pedaços de informações culturais passadas de pessoa para pessoa, gradualmente compartilhados em um fenômeno social" (tradução nossa ${ }^{4}$ ). Após analisar memes e seus efeitos no cotidiano, Calixto (2019, p. 150) oferece um novo significado para esse gênero:

Em termos de tipologia textual, memes relatam situações, fatos e expressões a partir de montagens e jogos de linguagem construídos

\footnotetext{
${ }^{4}$ Texto original: "First, memes may be understood as pieces of cultural information that pass along from person to person, but gradually scale into a shared social phenomenon". 
nas redes sociais. Com referências intertextuais e interdiscursivas aos produtos midiáticos que circulam no ciberespaço, os memes são narrativas que materializam - em micronarrativas - os enunciados formados por composições visuais-verbais, cuja finalidade é a interação com os pares. Nesse sentido, com personagens reais (como celebridades e atletas profissionais) ou imaginários (como animais de estimação que dialogam com humanos), os memes ocorrem de acordo com as cadeias comunicativas que os usuários da internet buscam ativar.

A pesquisa TIC Kids Online Brasil de 2018 constata que $83 \%$ dos estudantes do país utilizam a internet como meio de entretenimento, educação e interação. Isto posto, devido ao alto alcance de memes em redes sociais, essa apropriação de produtos culturais pode influenciar em como jovens estudantes constroem suas visões de mundo e percebem a realidade, já que "as montagens da internet são, em última instância, parte integrante da cultura construída pelos jovens" (CALIXTO, 2019, p. 136). Portanto, além de disseminadores de cultura, como proposto por Dawkins (2001), os memes vão de encontro às necessidades e contextos comunicativos dos usuários das mídias digitais contemporâneas, inseridos em seu enquadramento cultural. Em consonância, Ancleto e Filha (2017), caracterizam memes como:

Os memes caracterizam-se pela multimodalidade e exigem novas formas de leitura. Equivocadamente, podem ser tomados como materiais de conteúdo raso, superficial, apenas divertido e engraçado, sem nenhuma seriedade. Porém, são capazes de problematizar aspectos sociais, apresentando elementos da cultura, veiculados a diversas situações cotidianas. Sendo assim, geram ações discursivas, dando oportunidade aos sujeitos de expressarem opiniões e posicionamentos críticos, a partir de sua leitura. (p. 6)

Não podemos ignorar um dos elementos centrais dos memes: o humor. Ferreira e Vieira (2017, p. 03) afirmam que "o humor é hoje em dia reconhecido internacionalmente como um tema de maior importância nas relações entre culturas". A maioria dos memes apresenta conteúdo perfilado por deboches, provocações e claro, referências socioculturais, nas quais o humor pode funcionar como um canal de intervenção sobre o cotidiano. O jornalista Douglas de Oliveira Calixto (2019), assinala que os memes são uma forma de integração entre usuários da internet por meio da apropriação de produtos culturais que criam e significam conteúdos representativos e culturais. Logo, essas estruturas podem servir de respaldo para a construção de "pontes e interlocuções com os discentes" (CALIXTO, 2019, p. 151). 
Por serem, em sua maioria, humorísticos, os memes podem ser tratados com superficialidade e até certo desdém. Entretanto, esses textos multimodais revelam novos sentidos e significados por meio de palavras e imagens que, em conjunto, ultrapassam as barreiras do humor ingênuo, encobertos de elementos críticos culturalmente, socialmente e linguisticamente, "memes moldam mentalidades, formas de comportamento e ações de grupos sociais" (SHIFMAN, 2014, p. 18). Consequentemente, como os estudantes estão imersos no espaço virtual perante a Era Digital, eles precisam ser expostos a meios de compreensão e percepção de representações sociais, elementos socioculturais provenientes dos textos multimodais presentes nos memes que tanto encontram e compartilham na internet. À vista disso, Shifman (2014) discute três dimensões culturais que permitem às pessoas interagirem por meio de memes: conteúdo, forma e postura. Cani (2019, p. 252) explicita essas dimensões a seguir:

A primeira diz respeito ao conteúdo específico, relacionado tanto às ideias quanto às ideologias transmitidas pelo meme; a segunda dimensão aborda a forma, ou seja, a materialização física da mensagem, que possibilita a percepção sensorial (visual, auditiva ou outro padrão mais complexo); e a terceira considera a postura, a posição que os usuários assumem diante do gênero meme, por exemplo, a decisão de compartilhar um texto ou se posicionar contrário a ele.

Podemos evidenciar a natureza multimodal, ideológica e cultural de um meme diante das interações humanas no meio digital. Nas palavras de Orsini (2019, p. 305), “o meme e os elementos gráficos possuem outra grande vantagem: seu poder de síntese dos componentes sociais mais complexos e das ideias mais sofisticadas". Por possuir textos curtos atrelados às imagens, os memes podem conceder, ou até tornar mais acessível um conhecimento relacionado a determinado momento sócio-histórico-cultural e político, fazendo com que o estudante-leitor enxergue além do que lhe é apresentado no dia-a-dia. Isso se dá por meio do exercício do pensamento crítico perante gêneros midiáticos encontrados na internet.

Memes são constituídos de textos repletos de ideologias e conceitos que exigem a conexão com um conhecimento prévio por parte dos leitores, de modo a promoverem grandes impactos nas práticas comunicativas e sociais. Nesse sentido, espera-se que o professor/educador busque promover práticas sociais e digitais ao abordar temas que fazem parte da rotina do estudante, de forma a estabelecer uma relação de significância entre as línguas apresentadas em sala de aula, e as línguas utilizadas no mundo em que se vive. 


\section{PROPOSTAS PEDAGÓGICAS: E AGORA, CARO COLEGA PROFESSOR?}

Sabemos que a inserção de padrões interculturais no ensino de línguas estrangeiras/ adicionais não é tarefa fácil. Por isso, com o intuito de colaborar com possíveis práticas de colegas de profissão, com base nos preceitos teóricos explorados, foram elaboradas propostas de atividades pedagógicas englobando as contribuições das tecnologias digitais de informação e comunicação, utilizando memes como instrumento de ensino.

O objetivo do desenvolvimento dessas atividades é propiciar oportunidades de interação entre aluno/aluno, aluno/professor e aluno/mundo, além de promover o uso de meios multisemióticos a fim de resultar em um possível exercício da cidadania por meio da linguagem e interculturalidade. Isto posto, as atividades destinam-se aos seguintes idiomas: inglês e português para falantes de outras línguas (PFOL). Em relação ao segundo idioma aqui referido, as propostas apresentadas foram inspiradas em unidades didáticas presentes no Portal do Professor de Português Língua Estrangeira/Língua Não Materna (PPPLE5 5 ). O PPPLE é uma plataforma on-line, que tem como objetivo central oferecer à comunidade de professores e interessados em geral, recursos e materiais para $\mathrm{o}$ ensino e a aprendizagem do português como língua estrangeira/língua não materna.

Cada idioma contará com duas atividades, para níveis linguísticos distintos, separadas em três etapas: pré-atividade, atividade e pós-atividade.

\section{Língua Inglesa - Proposta I}

Esta proposta é destinada a alunos que apresentam níveis linguísticos entre A1 e A2, de acordo com o Quadro Europeu Comum de Referência para Línguas ${ }^{6}$.

- Objetivos: Discutir sobre preconceitos e estereótipos gerados a partir da disseminação do novo coronavírus (COVID19). Propor ações de conscientização perante a pandemia.

- Pré-Atividade: O professor irá mostrar os seguintes memes aos alunos (quadro 3) e elicitar comentários sobre a situação pandêmica atual e como/se os alunos se relacionam com as informações presentes nos memes.

\footnotetext{
${ }^{5}$ Disponível em: https://ppple.org/. Acesso em: 01 jun. 2020

${ }^{6}$ Disponível em: https://area.dge.mec.pt/gramatica/Quadro_Europeu_total.pdf. Acesso em: 31 maio 2020.
} 
Quadro 3: Memes a serem analisados.

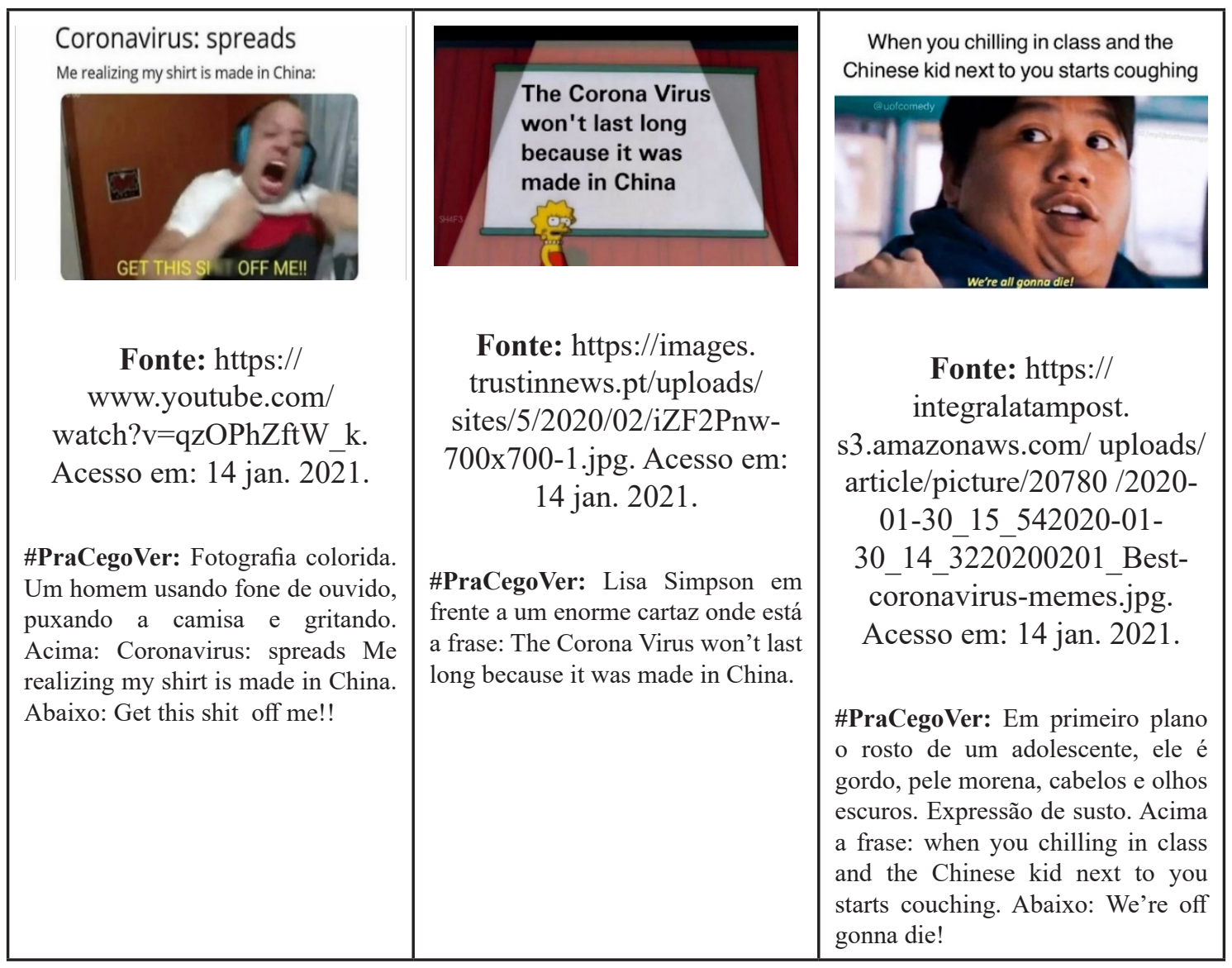

Fonte: As autoras.

- Atividade: Para trabalhar com fatos, os alunos irão assistir ao vídeo "What is a coronavirus?" 7 da plataforma Ted-Ed ${ }^{8}$, a qual se caracteriza como uma plataforma on-line que contém uma curadoria de vídeos da plataforma TED e animações próprias. O website oferece lições prontas sobre temas diversificados com opções de vídeo, compreensão, discussão e pensamento crítico. A plataforma também permite a customização de lições pelos professores. Depois de assistirem ao vídeo, os alunos irão trabalhar com algumas atividades de compreensão linguística e contextual $^{9}$. Posteriormente, os alunos e o professor irão discutir percepções

\footnotetext{
${ }^{7}$ Vídeo disponível em: https://www.youtube.com/watch?v=D9tTi-CDjDU

${ }^{8}$ Disponível em: https://ed.ted.com/

9 Atividades disponíveis aqui: https://ed.ted.com/lessons/what-is-a-coronavirus-elizabeth-cox/ review_open\#question-1
}

Revista X, v. 16, n. 2, p. 608-632, 2021. 
levantadas pelo vídeo, e como elas podem se conectar com os memes vistos anteriormente.

- Pós-Atividade: Após analisarem os fatos e discutirem os memes vistos, será a vez de o aluno criar o próprio meme sobre visões errôneas e estereotipadas quanto à China e ao novo coronavírus. Como este trabalho é um artigo de proposta, no qual os resultados e suas respectivas análises serão abordados em outro artigo, sugerimos que os alunos podem ser divididos em grupos para realizarem a criação dos memes, por meio do aplicativo Meme Generator. Se quiserem, podem compartilhar suas produções com outros grupos de alunos da mesma instituição.

\section{Língua Inglesa - Proposta II}

Esta proposta é destinada a alunos que apresentam níveis linguísticos entre B1 e B2, de acordo com o Quadro Europeu Comum de Referência para Línguas ${ }^{10}$.

- Objetivos: Discutir sobre práticas relacionadas à extração de petróleo no mundo, e como isso reflete na mudança climática do planeta. Propor reflexões e discussões sobre o tema.

- Pré-Atividade: Com a intenção de ativar os conhecimentos prévios dos alunos, o professor faz as seguintes perguntas: a) "Do you consume/use oil (petrol) in your daily life? How does that happen?"; b) "Has oil been a subject for intrigues and conflicts around the world? What do you know about it?". Em seguida, o professor pede para que os alunos analisem os seguintes memes (quadro 4):

${ }^{10}$ Disponível em: https://area.dge.mec.pt/gramatica/Quadro_Europeu_total.pdf. Acesso em: 31 maio 2020. 
Quadro 4: Memes a serem analisados.

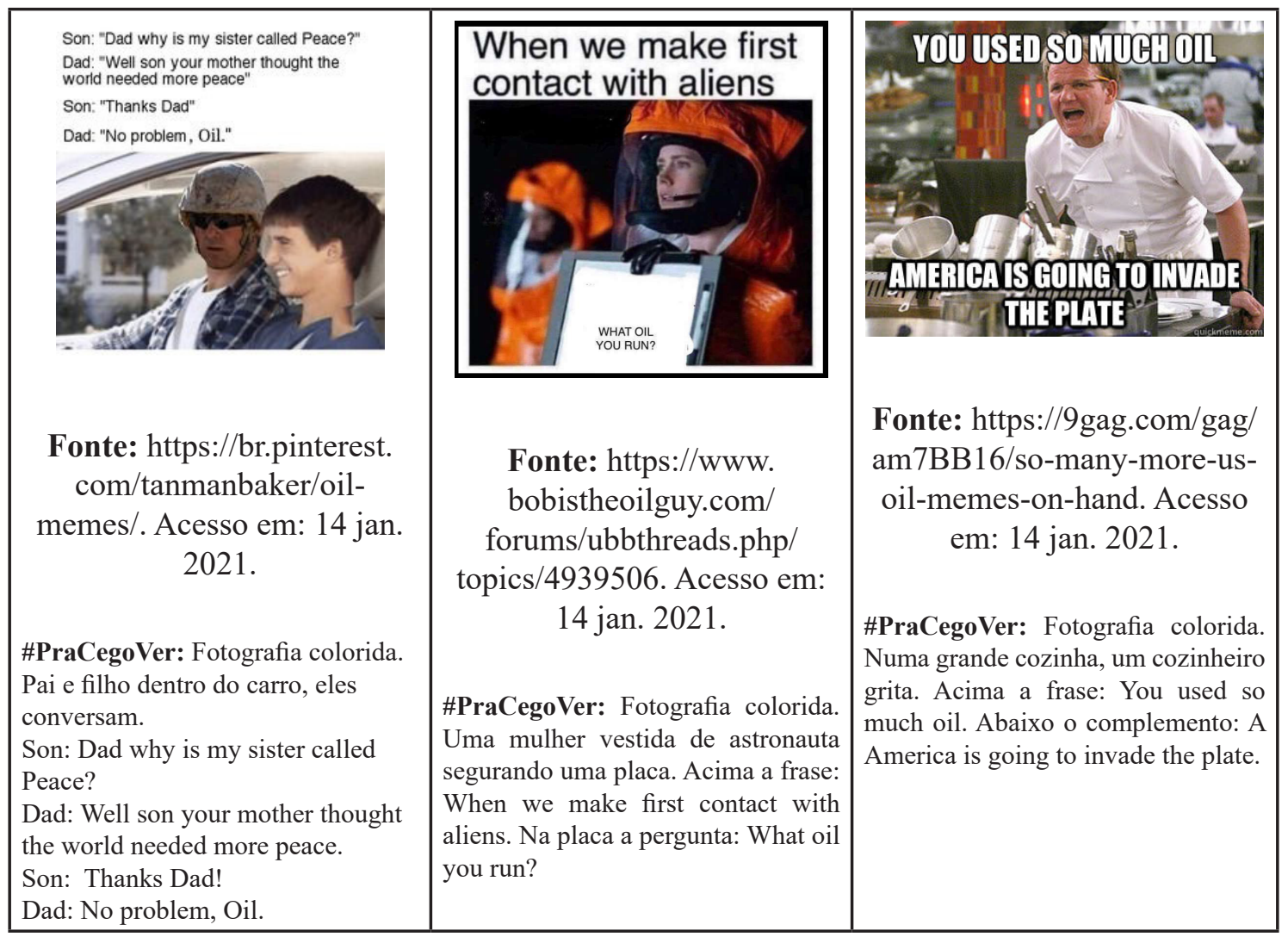

Fonte: As autoras.

- Atividade: Ao discutir cada meme com os alunos, o professor tem a oportunidade de explorar diferentes visões históricas sobre o domínio e a invasão territorial devido ao petróleo, abordar questões econômicas brasileiras acerca da indústria petrolífera, assim como avanços tecnológicos e referências à cultura com c minúsculo (KRAMSCH, 1993; HALL, 2010; BAUMAN, 2011) diante do meme sobre o filme $A$ Chegada e o reality show Hell's Kitchen. Após desenvolver a discussão, o professor irá dividir os alunos em duplas. Cada dupla irá ler uma notícia (quadro 5). Após as leituras, as duplas irão repassar para a turma o tema da notícia e irão propor uma questão para discussão. 
Quadro 5: Notícias para cada dupla.

\begin{tabular}{|c|c|c|}
\hline Duplas & Notícia & Fonte \\
\hline 1 & $\begin{array}{l}\text { Big Oil is using the coronavirus pandemic to } \\
\text { push through the Keystone XL pipeline }\end{array}$ & $\begin{array}{l}\text { https://www.theguardian.com/ } \\
\text { commentisfree/2020/apr/05/ } \\
\text { climate-crisis-villains-oil- } \\
\text { industry-big-banks-pipelines }\end{array}$ \\
\hline 2 & $\begin{array}{l}\text { Saudi crown prince's economic master plan } \\
\text { could be derailed by oil price crash }\end{array}$ & $\begin{array}{c}\text { https://edition.cnn. } \\
\text { com/2020/05/12/business/saudi- } \\
\text { arabia-oil-mbs/index.html }\end{array}$ \\
\hline 3 & $\begin{array}{l}\text { Investors call on Australia's largest oil and } \\
\text { gas company to set greenhouse targets }\end{array}$ & $\begin{array}{l}\text { https://www.theguardian.com/ } \\
\text { environment/2020/may/01/ } \\
\text { investors-call-on-australias- } \\
\text { largest-oil-and-gas-company-to- } \\
\text { set-greenhouse-targets }\end{array}$ \\
\hline 4 & $\begin{array}{l}\text { Makeshift oil refineries a necessary evil for } \\
\text { locals in north-west Syria }\end{array}$ & $\begin{array}{l}\text { https://www.theguardian.com/ } \\
\text { global-development/2020/ } \\
\text { apr/24/makeshift-oil-refineries- } \\
\text { a-necessary-evil-for-locals-in- } \\
\text { north-east-syria-study-finds }\end{array}$ \\
\hline 5 & $\begin{array}{l}\text { US shale industry expected to shrink sharply } \\
\text { as oil price falls }\end{array}$ & $\begin{array}{c}\text { https://www.theguardian.com/ } \\
\text { environment/2020/apr/17/us- } \\
\text { shale-industry-expected-shrink- } \\
\text { oil-price-falls }\end{array}$ \\
\hline 6 & $\begin{array}{c}\text { Oil-Starved Venezuela Celebrates Arrival of } \\
\text { Tankers From Iran }\end{array}$ & $\begin{array}{c}\text { https://www.nytimes. } \\
\text { com/2020/05/25/world/ } \\
\text { americas/Iranian-oil- } \\
\text { tankers-venezuela. } \\
\text { html? searchResultPosition=2 }\end{array}$ \\
\hline
\end{tabular}

Fonte: as autoras.

- Pós-atividade: Após discutirem as perguntas propostas, cada dupla irá elaborar um post para o Instagram apontando fatos levantados pelas leituras das notícias e discussões com os colegas, seguidos de uma pergunta que possa promover a 
reflexão dos leitores diante do post $^{11}$. Na sequência, os alunos irão compartilhar os posts em suas redes sociais, para que haja a desencapsulação do conhecimento em sala de aula, tornando-o mais significativo. Dessa forma, o aluno estará utilizando a linguagem como forma de agir no mundo.

\section{Português para falantes de outras línguas (PFOL) - Proposta I}

Esta proposta é destinada a alunos que apresentam níveis linguísticos entre A2 e B1, conforme o Quadro Europeu Comum de Referência para Línguas ${ }^{12}$.

- Objetivos: Refletir sobre conceitos estereotipados de diferentes culturas. Ampliar o conhecimento de mundo, no intuito de diminuir barreiras e choques culturais.

- Pré-atividade: O professor irá mostrar três textos aos alunos (quadro 6):

Quadro 6: Textos em língua portuguesa.

\begin{tabular}{|c|c|c|}
\hline $\begin{array}{l}\text { Bis Bruno } \\
\text { quis fazer drama pra cima de mim } \\
\text { logo eu }\end{array}$ & $\begin{array}{l}\text { De. xuxa } \\
\text { me tratou como criança } \\
\text { logo eu } \\
\text { rainha dos baixinhos }\end{array}$ & 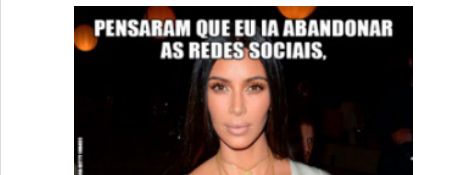 \\
\hline & 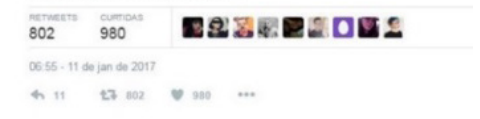 & 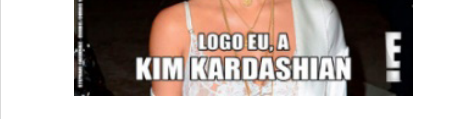 \\
\hline $\begin{array}{l}\text { Fonte: https://img.r7.com/ } \\
\text { images/2017/01/11/ } \\
\text { 1kr6e7iwz_5um0dbb6t7 } \\
\text { file?dimensions }=780 \times 340\end{array}$ & $\begin{array}{c}\text { Fonte: https:/www. } \\
\text { museudememes.com.br/ } \\
\text { wpcontent/ uploads/2017/03 } \\
\text { /18642693080009305600000. } \\
\text { jpg }\end{array}$ & $\begin{array}{c}\text { Fonte: https://www.eonline. } \\
\text { com/br/news/822151/a- } \\
\text { superacao-da-internet-com- } \\
\text { os-memes-do-logo-eu. Acesso } \\
\text { em: } 14 \text { jan. } 2021 \text {. }\end{array}$ \\
\hline $\begin{array}{l}\text { \#PraCegoVer: Print do Twiter do } \\
\text { usuário Bruno: quis fazer drama pra } \\
\text { cima de mim, logo eu, a maria do } \\
\text { bairro. }\end{array}$ & $\begin{array}{l}\text { \#PraCegoVer: Print do Twiter } \\
\text { da usuária Xuxa: me tratou como } \\
\text { criança, logo eu, rainha dos } \\
\text { baixinhos. }\end{array}$ & $\begin{array}{l}\text { \#PraCegoVer: Fotografia colorida. } \\
\text { No centro a Kim Kardashian. Ela tem } \\
\text { pele clara, cabelos longos e pretos, } \\
\text { olhos escuros. Usa uma blusa branca } \\
\text { de alças. Acima: Pensaram que eu ia } \\
\text { abandonar as redes sociais. Abaixo: } \\
\text { Logo eu, a Kim Kardashian. }\end{array}$ \\
\hline
\end{tabular}

Fonte: as autoras.

${ }^{11}$ Os alunos podem criar o post utilizando a ferramenta CANVA. Acesso: https://www.canva.com/ search/templates?q=Posts\%20para\%20Instagram\&category=tACFajEYUAM \&doctype=TABQqs5Kbyc \&order $=\mathrm{B}$

${ }^{12}$ Disponível em: https://area.dge.mec.pt/gramatica/Quadro_Europeu_total.pdf. Acesso em: 31 maio 2020.

Revista X, v. 16, n. 2, p. 608-632, 2021. 
- Atividade: O professor e os alunos irão discutir as referências de cada texto em grupos. Como pode-se notar, cada um deles faz referência a uma cultura diferente. O primeiro refere-se a uma novela mexicana, o segundo a uma apresentadora brasileira, e o terceiro a uma celebridade estadunidense. Com isso, para ter a oportunidade de contar um pouco mais sobre a cultura de seu país de origem, cada aluno irá elaborar um post no Padlet ${ }^{13}$ seguindo o modelo dos posts analisados na atividade anterior. Padlet é uma ferramenta online que permite a criação de um mural ou quadro virtual dinâmico e interativo para registrar, guardar e partilhar conteúdos multimídia. Funciona como uma folha de papel, onde se pode inserir qualquer tipo de conteúdo (texto, imagens, vídeo, hiperlinks) juntamente com outras pessoas. Com a mesma conta pode-se criar vários murais.

- Pós-atividade: Após completarem o Padlet com características de seus países de origem, os alunos irão apresentar seu post de maneira a interagir com os outros alunos, contrastando diferenças e semelhanças da cultura midiática encontradas em seus respectivos países de origem.

\section{Português para falantes de outras línguas (PFOL) - Proposta II}

Esta proposta é destinada a alunos que apresentam níveis linguísticos entre B1 e B2, de acordo com o Quadro Europeu Comum de Referência para Línguas ${ }^{14}$.

- Objetivos: Discutir sobre aspectos identitários de diferentes nações. Trabalhar com produção escrita e pensamento crítico na língua-alvo.

- Pré-atividade: O professor irá perguntar aos alunos se eles têm familiaridade com o termo "gambiarra". Em seguida, irá apresentar as seguintes definições (quadro 7):

\footnotetext{
13 Tutorial disponível em: https://inovaeh.sead.ufscar.br/wp-content/uploads/2019/04/TutorialPadlet.pdf. Acesso em: 01 jun. 2020.

${ }^{14}$ Disponível em: https://area.dge.mec.pt/gramatica/Quadro_Europeu_total.pdf. Acesso em: 31 maio 2020.
} 
Quadro 7: Definições de "gambiarra".

1. Solução improvisada para resolver um problema ou para remediar uma situação de emergência; remendo. (DICIO - Dicionário Online de Português. Disponível em: https:// www.dicio.com.br/gambiarra. Acesso em: 01 jun. 2020.

2. Solução improvisada para resolver um problema ou uma necessidade (ex.: fez uma gambiarra para que o carro andasse). (Dicionário Priberam. Disponível em: https:// dicionario.priberam.org/gambiarra. Acesso em: 01 jun. 2020).

3. Trabalho feito com improviso, com peças alternativas. (Ex: Tive que fazer uma gambiarra pra instalar o som no carro, mas pelo menos está funcionando). (Dicionário informal. Disponível em: https://www.dicionarioinformal.com.br/gambiarra/. Acesso em: 01 jun. 2020.

Fonte: as autoras.

Em seguida, o professor irá mostrar os seguintes memes (quadro 8):

Quadro 8: Memes sobre "gambiarra".

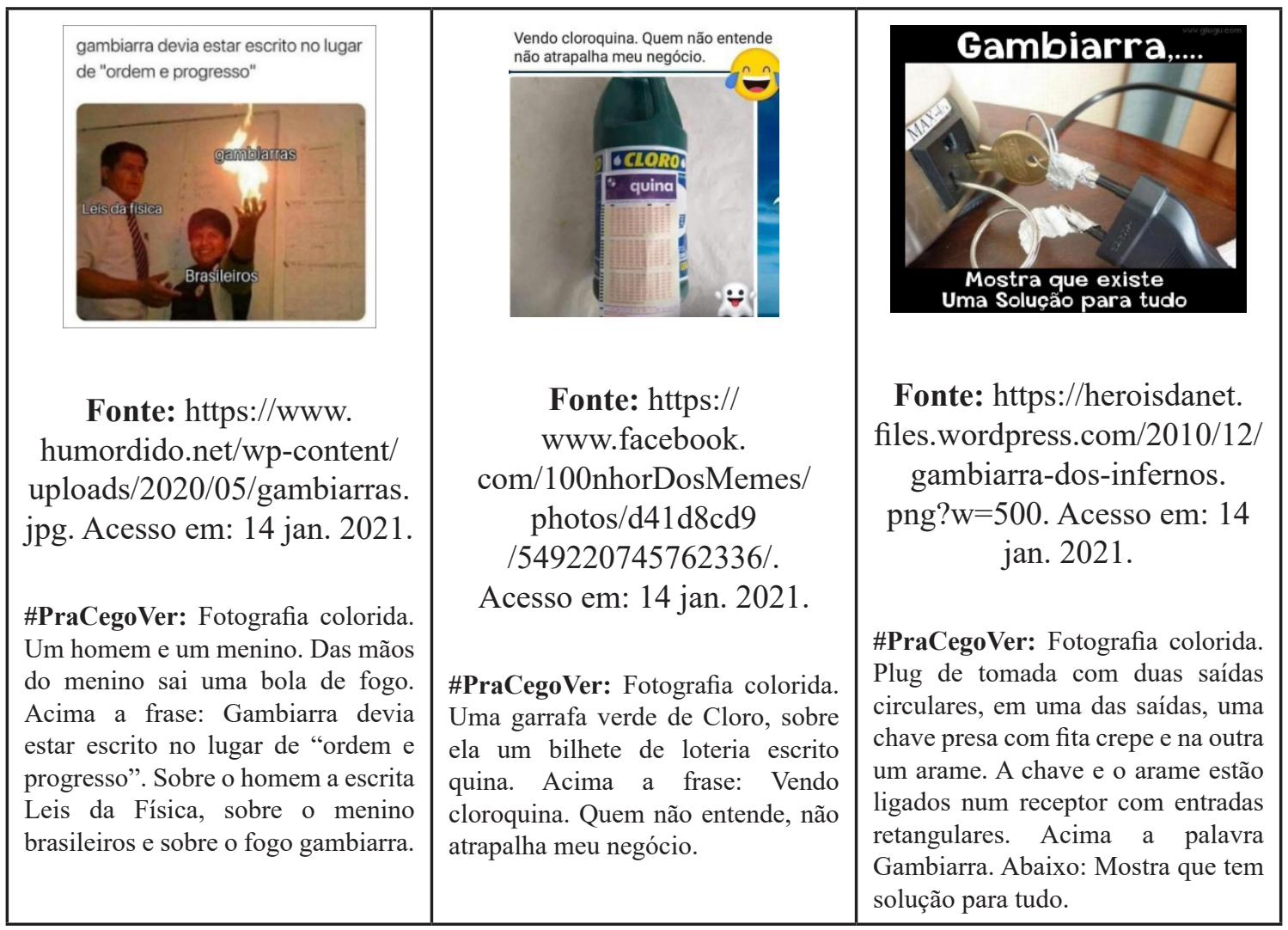

Fonte: as autoras.

Revista X, v. 16, n. 2, p. 608-632, 2021. 
- Atividade: Coletivamente, o professor e os alunos irão discutir como a palavra "gambiarra" se conecta à cultura brasileira e analisar alguns exemplos em uma página do BuzzFeed ${ }^{15}$ - 20 gambiarras que falam mais sobre a alma do brasileiro do que o Hino Nacional. Depois de acessarem a página, os alunos irão pensar e explicitar aos colegas se o conceito de "gambiarra" existe de alguma outra forma em suas culturas.

- Pós-atividade: Como podemos observar na atividade, o "jeitinho brasileiro" é presente e conhecido em todo país. Os alunos serão convidados a refletir sobre o "jeitinho" característico de seu próprio país, algo que seja popularmente conhecido e visto como uma prática recorrente em sua nação. Entretanto, o professor chamará atenção para a visão que aquela característica pode causar perante o olhar do outro. A proposta então é para que os alunos escrevam um texto sobre como podemos mudar nosso olhar perante o outro. $\mathrm{O}$ texto pode ser escrito em formato de tópicos curtos, caso o aluno assim prefira. Realizado o processo de correção da escolha do professor, os alunos serão convidados a postarem seus textos no Facebook com o intuito de promover a desencapsulação da aprendizagem e utilizar a língua como prática social, com o objetivo de divulgar o conteúdo discutido em sala de aula.

\section{CONSIDERAÇÕES FINAIS}

Neste artigo, discutimos questões teórico-práticas a partir do gênero meme, o qual une texto verbal e não-verbal e evidencia aspectos linguístico-culturais, humorísticos e/ ou críticos. Pretendemos demonstrar que tecnologias digitais e matizes culturais estão implícitas nas propostas pedagógicas apresentadas utilizando memes em aulas de línguas estrangeiras/adicionais.

Esperamos explicitar que as tecnologias digitais e os memes podem e deveriam ser utilizados nas aulas de línguas porque fazem com que o professor se aproxime da linguagem dos alunos, visto que ambos os elementos estão presentes em nosso cotidiano e são exemplos da realidade contemporânea. Por conseguinte, por que não nos valermos das tecnologias e dos memes em prol do processo de ensino e aprendizagem, uma vez que inovar é preciso, sobretudo em tempos tão imprecisos?

Concluímos que os memes são um recurso válido que torna possível reinventar as aulas de línguas, tornando-as mais lúdicas, agradáveis e eficazes, entrelaçando em

15 Disponível em: https://www.buzzfeed.com/br/manuelabarem/gambiarras-que-falam-maissobre-a-alma-do-brasileiro-do-q. Acesso em: 01 jun. 2020.

Revista X, v. 16, n. 2, p. 608-632, 2021. 
perfeita harmonia saber e diversão. Como se constatou no decorrer deste artigo, memes refletem aspectos culturais que marcam determinado momento sócio-histórico e político e identificam comunidades linguístico-culturais ao trazer especificidades e particularidades típicas de cada língua/cultura.

Em suma, acreditamos ser possível trabalhar de forma eficaz e diversificada ao contemplarmos memes em aulas de línguas, pois são recursos que agradam jovens e adultos, deixando as aulas mais leves e o filtro afetivo mais receptivo a novos saberes.

\section{REFERÊNCIAS}

ANECLETO, U.; FILHA, I. Ensino de língua portuguesa e memes: outros textos, outras leituras. Revista A Cor das Letras, Feira de Santana, v. 18, n. 3, 2017, p. 43-53. Disponível em: http://periodicos.uefs.br/ojs/index.php/acordasletras/article/view/2054. Acesso em: 02 jun. 2020.

ANTUNES, I. Aulas de português: encontro e interação. São Paulo: Parábola Editorial, 2003.

ARAÚJO, M. A. F. de; FIGUEIREDO, F. J. Q. de. Cultura, interculturalidade e sala de aula de língua estrangeira: múltiplas perspectivas. REVELLI - Revista de Educação, Linguagem e Literatura, v.7, n.1, Junho, 2015, p. 63-76. Disponível em: https://www. revista.ueg.br/index.php/revelli/article/view/3502/2543. Acesso em: 05 jan. 2021.

BAUMAN, Z. Culture in a Liquid Modern World, Cambridge: Polity Press, 2011.

CALIXTO, D. Memes na internet: entrelaçamentos entre a "zoeira" de estudantes e a apropriação do gênero discursivo na escola. Revista Periferia, v. 11, n. 2, p. 131-152, maio/ago. 2019. Disponível em: https:/www.e-publicacoes.uerj.br/index.php/periferia/ article/view/36457. Acesso em: 29 maio 2020.

CANI, J. B. Multimodalidade e efeitos de sentido no gênero meme. Periferia, v. 11, n. 2, p. 242-267, 2019. Disponível em: https://www.e-publicacoes.uerj.br/index.php/periferia/ article/view/36955. Acesso em: 29 maio 2020.

COMITÊ GESTOR DA INTERNET NO BRASIL. Pesquisa TIC KIDS ONLINE 2018: Cresce uso da Internet em atividades multimídia entre crianças e adolescentes. São Paulo: GCI.br, 2019. Disponível em: https://www.cgi.br/noticia/releases/cresce-uso-da-internetem-atividades-multimidia-entre-criancas-e-adolescentes/. Acesso em 29 maio 2020. 
DAWKINS, R. O Gene egoísta. Coleção O Homem e a Ciência, v. 7. Belo Horizonte: Itatiaia, 2001. Disponível em: https://books.google.com.br/books?hl=pt-BR\&lr=\&id=zg UmDwAAQBAJ\&oi $=$ fnd $\& p g=P T 2 \& d q=D A W K I N S,+$ Richard $.+\mathrm{O}+\mathrm{Gene}+$ ego $\% \mathrm{C} 3 \% \mathrm{~A}$ Dsta.+\&ots=B8QWzVhr_3\&sig=PCUoARxdiwpV1PdJ1VoxqbWrblM. Acesso em: 29 maio 2020.

DURÃO, A. B. A. B. A importância da explicitação de matizes culturais particulares no ensino de língua estrangeira. Signum, v.2, 1999. p.139-154.

Psiu? Você quer saber mais sobre as línguas? (5) Folha Nossa. Ano 2. n.12. Julho, 2002. p. 6-7.

JENKINS, H.; FORD, S.; GREEN, J. Cultura da Conexão: criando valor e significado para a mídia propagável. São Paulo: Aleph, 2014.

FERREIRA, C. C. Abre alas que eu quero passar. Não só a festividades se resume trabalhar (inter/trans)culturalidade: reflexões teóricas e propostas pedagógicas. In: FERREIRA, Cláudia Cristina; MIRANDA, Caio Vitor Marques. (Re)Visões sobre o processo de ensino e aprendizagem de línguas estrangeiras/adicionais: conjugação entre teoria e prática. Campinas: Pontes, 2020. p. 13-56.

FERREIRA, C. C. É possível ser competente em língua estrangeira? In: ZORZOVELOSO, V. F.; FERREIRA, C.C.; ORTIGOZA, A. F. El español en línea de mira: enlaces lingüísticos, literarios y metodológicos. Londrina: Universidade Estadual de Londrina, 2013, p. 67-83.

. Mais um abacaxi para descascar ou uma mão na roda? Os culturemas no processo de ensino e aprendizagem de línguas estrangeiras/adicionais. Vade mecum do ensino das línguas estrangeiras/adicionais. Campinas: Pontes, 2018. p. 491-524.

FERREIRA, C. C.; DURÃO, A. B. A. B. Não confunda alhos com bugalhos nem pise em ovos... Aproximações teórico-metodológicas sobre culturemas no processo de ensino e aprendizagem e no fazer tradutório de línguas estrangeiras/adicionais. (no prelo)

FERREIRA, J. P. R.; VIEIRA, T.L. Humor, língua e linguagem: representações culturais. São Paulo: Verona, 2017.

GIMENEZ, T. Eles comem corn flakes, nós comemos pão com manteiga: espaços para a reflexãosobreculturanasaladeauladelínguaestrangeira.AnaisdoIXEncontrodeProfessores de Línguas Estrangeiras - IX EPLE. Londrina: APLIEPAR, 2001.p. 107-114. Disponível em: https://www.academia.edu/1296067/Eles_comem_cornflakes_n\%C3\%B3s_ comemos_p\%C3\%A3o_com_manteiga_espa $\% \mathrm{C} 3 \% \mathrm{~A} 7 \mathrm{os} \_$para_reflex\%C3\%A3o_ sobre_cultura_na_aula_de_1\%C3\%ADngua_estrangeira. Acesso em: 05 jan. 2021. 
HALL, J; GRINDSTAFF, L; LO, M. C. Handbook of Cultural Sociology, London: Routledge, 2010.

KRAMSCH, C. Context and culture in language teaching. Introduction. Oxford University Press, 1993. Disponível em: https://books.google.com.br/books?hl=pt-BR\&lr=\&id=7 3rFnM6qlrwC\&oi $=$ fnd $\& p g=P P 10 \& d q=K R A M S C H,+C .+$ Context + and + culture + in + la nguage+teaching\&ots $=$ oBMO4UUEWg\&sig $=$ ojTKuG4zwbDpkS7F1UmtMttGWSA. Acesso em: 31 maio 2020.

LAINESTE, L.; VOOLAID, P. Laughing across borders: intertextuality of internet memes. European Journal of Humour Research v.4, 2017, p. 26-49. Disponível em: https://www.europeanjournalofhumour.org/index.php/ejhr/article/view/165. Acesso em: 29 maio 2020.

LUQUE DURÁN, J. de D. Estereotipos, automatismos y juegos del linguaje en el Diccionario Cultural. In: Luque Toro, Luis (ed.), Léxico Español Actual II. Venezia: Editrice Ca'Foscarina, p. 109-130, 2019. Disponível em: http://157.138.8.12/jspui/ bitstream/11707/848/1/08\%20Duran.pdf. Acesso em: 05 jan. 2021.

LUQUE NADAL, L. Los culturemas: ¿unidades linguísticas, ideológicas o culturales? Language Design, 11, p. 93-120, 2009. Disponível em: http://elies.rediris.es/Language_ Design/LD11/LD11-05-Lucia.pdf. Acesso em: 14 dez. 2020.

MONTEIRO-PLANTIN, R. S. Fraseologia - era uma vez um patinho feio no ensino de língua materna. Fortaleza: Edições UFC, 2012. v.1. Disponível em: Acesso em: 20 fev. 2018.

ORSINI, E. F. M. F. Educação, memes e a categoria trabalho. Revista Periferia, v. 11, n. 2 , 2019, p. 291-316. Disponível em: https:/www.e-publicacoes.uerj.br/index.php/periferia/ article/view/35086. Acesso em: 29 maio 2020.

RECUERO, R. Memes e Dinâmicas Sociais em Weblogs: Informação, capital social e interação em redes sociais na Internet. XXIX INTERCOM, Tecnologias da Informação e Comunicação, Brasília/DF, 2006.

SHIFMAN, L. Memes in Digital Culture. Londres, Inglaterra: The MIT PRESS, 2014.

WALSH, C. Interculturalidade e decolonialidade do poder: um pensamento e posicionamento "outro" a partir da diferença colonial. Revista Eletrônica da Faculdade de Direito da Universidade Federal de Pelotas (UFPel), V. 05, N. 1, Jan.-Jul., 2019. Disponível em: https://periodicos.ufpel.edu.br/ojs2/index.php/revistadireito/article/ view/15002/10532. Acesso em: 05 jan. 2021. 
WIGGINS, B. The discursive power of memes in digital culture: Ideology, semiotics, and intertextuality. New York, NY: Routledge, 2019.

Recebido em: 03 set. 2020.

Aceito em: 19 jan. 2021. 